$1-1-2018$

\title{
Medicalization of Rural Poverty: Challenges for Access
}

\author{
Elizabeth Weeks \\ Associate Dean for Faculty Development \& J. Alton Hosch Professor of Law University of Georgia Main \\ Campus,weeksleo@uga.edu
}

University of Georgia School of Law

Research Paper Series

Paper No. 2018-06

p bepress $S$ Tren

\section{Repository Citation}

Elizabeth Weeks, Medicalization of Rural Poverty: Challenges for Access , 46 J.L. Med. \& Ethics 651 (2018),

Available at: https://digitalcommons.law.uga.edu/fac_artchop/1193

This Article is brought to you for free and open access by the Faculty Scholarship at Digital Commons @ University of Georgia School of Law. It has been accepted for inclusion in Scholarly Works by an authorized administrator of Digital Commons @ University of Georgia School of Law. Please share how you have benefited from this access For more information, please contact tstriepe@uga.edu. 


\section{Medicalization of Rural Poverty: Challenges for Access}

\author{
Elizabeth Weeks
}

$\mathrm{R}$ ecent studies starkly reveal that rural Americans suffer from a particular constellation of socioeconomic and related health challenges. To effectively address those challenges, any social policy prescription must be fine-tuned for rural populations. To that end, this article identifies four critical insights: First, rural poverty is different. Rural poverty historically has been marginalized in academic studies of poverty for a variety of reasons, a few of which are explained below. ${ }^{1}$ Second, rural health is different. Rural-urban health disparities are well documented, a reality that further emphasizes the importance of designing health care access and public health strategies with those communities in mind. In recent decades, much of the country has benefited from economic recovery ${ }^{2}$ and improved life expectancy. ${ }^{3}$ But the same has not been true for rural America. ${ }^{4}$ Economic despair leads to diseases of despair. Third, rural health care is different. Certain features of the existing health care financing and delivery system particularly and adversely impact rural health. Sweeping federal health reform under the Patient Protection and Affordable Care Act of $2010^{5}$ did little to help - and may have even hindered - rural health care access. Finally, because of those differences, rural health strategies need to be different. What follows is a broad-brush overview and agenda for further research. ${ }^{6}$

\section{Rural Poverty Is Different}

Much of the existing academic scholarship has focused on causes and effects of urban poverty, while rural poverty has only recently received discrete attention. But rural poverty merits separate consideration. ${ }^{7}$ During the 1950s and 1960s, rural poverty rates often were twice as high as urban areas. ${ }^{8}$ The gap has narrowed over time but remains noteworthy. In 2015, 16.7 percent of the rural population was poor, compared to thirteen percent in urban areas and 10.8 percent in suburban areas. ${ }^{9}$ The rural-urban poverty rate gap also varies by region. Historically, the gap has been the greatest in the South. ${ }^{10}$

Rural poverty is not only greater but has deeper roots than urban poverty. Rural counties comprise the vast majority ( $85 \%$ ) of counties nationwide that are deemed "persistently poor." Persistently poor is defined as counties in which $20 \%$ or more of the population was living in poverty in three consecutive decennial censuses. ${ }^{11}$ Fifteen percent of all nonmetro counties fall in that category. ${ }^{12}$

Elizabeth Weeks, J.D., is Associate Dean for Faculty Development and J.Alton Hosch Professor of Law at the University of Georgia School of Law. 
The primary point at this first juncture of the roadmap is not to belabor the demographics but to point out that existing poverty research may not fully capture rural populations. The research trend is shifting, and recent studies have drawn attention to rural and suburban poverty issues, noting particular features of and challenges for those geographic areas. ${ }^{13}$

There are a number of possible explanations for the historical bias towards research on urban poverty, dating back to the Industrial Revolution. For one, institutions of higher learning tend to be in urban areas, with greater population density and closer proximity to research subjects. ${ }^{14}$ Moreover, rural sociology as a field was often marginalized, relegated to schools of agriculture. ${ }^{15}$ As a result, rural poverty remained an academic afterthought.

Other commentators suggest that race plays a factor in the academic under- attention to rural poverty. According to the 2010 decennial U.S. census, seventy-eight percent of residents of rural areas identify as white. ${ }^{16}$ While rural poverty is hardly limited to whites, that feature challenges the academic narrative. ${ }^{17}$ Researchers and policymakers can articulate a story about Black poverty as stemming from the legacies of slavery, Jim Crow, housing discrimination, employment discrimination, and incarceration rates and, accordingly, direct strategies toward those disparities. By contrast, there is not as clearly a "good reason" for whites to be poor, ${ }^{18}$ and thus not as clear of a roadmap for addressing the problem. ${ }^{19}$

By highlighting the "whiteness" of rural poverty, I do not mean to suggest that rural Blacks, Hispanics, Native Americans, and other groups are not suffering in significant ways that also merit attention. ${ }^{20}$ And there is a risk that overemphasizing that narrative will draw policy attention and resources away from longstanding issues affecting minority populations in favor of new issues affecting other groups.

Policymakers' responses to the opioid crisis have been criticized in those terms - opioids, which heavily impact whites, is a public health epidemic, while crack, a significant proglem for minorities, was addressed through stricter law enforcement and steeper sentencing. ${ }^{21}$ My point is not to belabor that issue but to note one possible explanation for why existing research may not fully capture the range of unique challenges associated with poverty in rural America. To properly address rural poverty through the health care system, we first will need to better understand its etiology and progression.

\section{Rural Health Is Different}

For decades, the United States generally has enjoyed a positive trend in life expectancy. ${ }^{22}$ But the same is not true for rural areas, where life expectancy gains have been slower, or even declining. ${ }^{23}$ Nationwide, however, the trend has reversed for the past two years; the first such two-year downturn in life expectancy since the early 1960s. The recent trend seems to be caused at least in part by the opioid epidemic, ${ }^{24}$ which, as discussed below, impacts rural America in particularly dramatic ways.

Other health markers similarly reveal rural-urban health disparities. A 2017 study from the Centers for Disease Control and Prevention highlights health risks particular to rural residents. ${ }^{25}$ Rural Americans are more likely than their urban counterparts to die from five causes: Cancer, heart disease, chronic lower respiratory disease, stroke, and accidental injuries. ${ }^{26}$ Notably, all of those causes are potentially preventable, suggesting a roadmap for rural public health strategies focusing on tobacco cessation, diet and exercise, motor vehicle safety, screening and early detection, and safer opioid prescribing practices.

The CDC report echoes and partially confirms findings in Ann Case and Angus Deaton's influential but controversial 2015's study. The researchers, Princeton economists, revealed that while mortality rates for Blacks and Hispanics in the U.S. decreased from 1999 to 2015 , mortality rates among middle-aged whites increased over the same time period. Rural whites had the largest increase among all middle aged adults. ${ }^{27}$ Case and Deaton highlighted rural disparities impacting health, including loss of job opportunities, lack of access to health care, isolation, poor health behaviors and attitudes, higher smoking rates, more sedentary lifestyles, and mental health stigma..$^{28}$

Consistent with the CDC's later study, the causes of those deaths seem to be preventable and include chronic diseases as well as suicide and accidental poisoning (including from opioids). ${ }^{29}$ Case and Deaton coined the term "despair deaths" to describe the trend of rising morbidity and mortality among middle-aged white non-Hispanic Americans. ${ }^{30}$ They suggest that it results in part from the stress and hopelessness of that subpopulation as they enter bleak job markets, doing worse than prior generations. ${ }^{31}$ That despair leads to family dysfunction, poor social support, and addiction, as individuals turn to food, alcohol, tobacco, opiates, and suicide.

The Case and Deaton study is controversial because their data tend to mask longstanding, persistent disadvantages and disparities for minorities, especially Blacks. To be sure, Blacks have and continue to suffer from premature death from all causes. ${ }^{32}$ Case and Deaton, thus, are criticized for overemphasizing a relatively modest increase in adversity that non-Hispanic whites are facing. ${ }^{33}$ Accepting those caveats, the study 
nevertheless is informative for rural health at least in painting a picture of a particular and significant segment of the rural population.

Again, the point is not to ignore health disparities for racial and ethnic minorities ${ }^{34}$ but to highlight the surprising finding regarding health status of a group that historically seemed to have the cards stacked in its favor. Blacks, Hispanics, Asians, and other minority groups are not necessarily doing well, but they are not doing worse than their parents. Middle-aged white Americans, by contrast, may be acutely aware of their failings, compared to their parents' and grandparents' generations.

The "diseases of despair" narrative also captures another critical feature of rural health - the opioid crisis or epidemic, now an officially recognized public be licensed under state law to provide a full range of services. ${ }^{42}$

Lack of reliable public and private transportation, poor Internet connectivity, lack of employment (and, accordingly, lack of health insurance coverage) further impair access to care in rural areas. Access to highspeed broadband is a necessary precursor to expanding access to care through telemedicine as well as for rural residents' ability to access online resources for health education, promotion, monitoring, and tracking. Access to mental health and substance abuse treatment is especially challenging in rural areas due to personnel and facility shortages and relatively greater social stigma around mental illness. ${ }^{43}$

Since 2010, the year of the ACA's enactment, 83 rural hospitals nationwide have closed. ${ }^{44}$ In my state of Georgia, we have had five rural hospital closures in that time. ${ }^{45}$ Texas has had ten. ${ }^{46}$ A variety of intricate legislative and regulatory changes have contributed to this trend. For one, under the ACA's promise of near-universal health insurance coverage, lawmakers cut disproportionate share hospital (DSH) funds. ${ }^{47}$ DSH funds historically were designed to alleviate hospitals' financial burden of providing uncompensated care. Under

health emergency. ${ }^{35}$ Data show a clear pattern of higher rates of opioid-related deaths (namely, overdoses) and babies born addicted to opioids in rural areas. ${ }^{36}$ Research from my state of Georgia reveals that the majority of counties with drug overdose rates exceeding the national average are rural. ${ }^{37}$ Many factors may contribute to the pronounced impact of opioid misuse in rural populations -economic despair, the large elderly rural population, prescribing practices, health professional shortages, and difficulty accessing routine medical care, physical therapy, emergency care, and mental health treatment. ${ }^{38}$

\section{Rural Health Care Is Different}

Rural health care financing, delivery, and access also are markedly different from urban health care. Escalating costs of health care impair individuals' ability to access health care nationwide. ${ }^{39}$ Some people remain uninsured, and others find co-payments and deductibles prohibitively high. Those effects are particularly acute for rural areas. ${ }^{40}$ In addition, medical providers and professionals simply may be unavailable, even if there were a way to pay for them. Health care provider shortages have long challenged rural health care delivery. One-fifth of Americans live in rural areas, but only one-tenth of physicians practice there. ${ }^{41}$ Even where mid-level providers may be available, they may not the ACA, the expectation was that with most people covered, the need for DSH subsidies would be largely obsolete. Unfortunately, even as it became clear that universal coverage was far from being achieved, DSH funding was not reinstated. Moreover, Medicare cuts unrelated to the ACA and changes to Medicare reimbursement policies, including strategies to align payment with quality rather than volume, operated adversely for many rural providers. ${ }^{48}$ Rural hospitals tend to be particularly dependent on government health care program revenue. ${ }^{49}$ Additional regulatory compliance requirements, including but not limited to hit rural hospitals especially hard.50 These hospitals characteristically have especially thin operating margins, making it difficult to bear the added burdens..$^{51}$

A particularly pronounced challenge for rural providers is the ACA's Medicaid expansion provision being restyled from mandatory to optional. Under the ACA, as enacted, all low-income Americans (below $138 \%$ of federal poverty level) would have been eligible for government health insurance. But in the face of states' constitutional challenges to mandatory Medicaid expansion, the U.S. Supreme Court allowed states to elect whether to maintain their existing Medicaid eligibility rules, which turned on certain categories (such as age, disability, pregnancy, or, in some new tax code provisions for tax-exempt hospitals, have 
cases, parenthood), or to expand their Medicaid coverage to the poor, regardless of categorical eligibility rules. ${ }^{52}$ Despite the fact that the federal government would almost fully fund the expansion, a number of states, including those with significant rural populations, thus far, have turned down the option. Medicaid opt-out decisions especially impact rural hospitals and other providers..$^{53}$ Medicaid non-expansion makes those hospitals increasingly vulnerable to closure, thereby exacerbating access to care challenges for rural areas. ${ }^{54}$

Commercial insurance markets, including the ACA's health insurance exchanges, also operate differently in rural areas, decreasing the availability of coverage for those ineligible for government health care programs or employer-sponsored insurance. Early numbers (from 2014, the first year that many important ACA insurance market reforms, including the individual

\section{Rural Health Strategies Need to Be Different}

Recognizing unique features of rural health should create more effective prescriptions for preventing and treating those maladies. Some approaches to the problem of access to care are longstanding, such as the loan forgiveness programs for rural health care providers, and the Anti-kickback Statute's (AKS) safe harbor for physician recruitment to Health Professional Shortage Areas (HPSAs). Signing bonuses, moving expenses, malpractice coverage, and other possible terms of physician recruitment packages raise the specter of violating both the AKS and Physician Self-Referral Prohibition (or Stark Law). The AKS, however, provides a safe harbor for such payments in the context of recruiting a physician to a designated HPSA, as long as other criteria are also met. ${ }^{63}$ Other ideas include malpractice liability insurance premium relief and tax credits for rural

\section{Poverty in rural America exhibits unique causes and challenges. Rural health care access is particularly fraught. Accordingly, rural health care interventions, with respect to both health care delivery and public health promotion, need to be uniquely tailored to this subpopulation of the American poor.}

mandate, took effect) did not suggest that the ACA's geographic rating factors disfavored rural areas..$^{55} \mathrm{~A}$ recent study from University of Iowa, however, reveals that 2016 premium rates increased disproportionately in rural areas. ${ }^{56}$ The study found that premium rates correlate with the number of firms offering health insurance. ${ }^{57}$ Thus, fewer firms in rural areas translate to higher premiums. In addition, market instability introduced by the Trump administration's reduced open enrollment period ${ }^{58}$ and lack of promotion for the private insurance marketplace exchanges ${ }^{59}$ predictably led to further premium increases. Even more significantly, the federal government ceased payment to insurance companies under the ACA's cost-sharing reduction payments, a move that is now being challenged in litigation. ${ }^{60}$ And Congress effectively repealed the tax penalty associated with the individual health insurance mandate, which creates further uncertainty. ${ }^{61}$ Although wholesale repeal and replacement of the ACA has not occurred, these changes alone will very likely result in premiums rising, ${ }^{62}$ including in rural areas. providers. Rural dental clinics, rural health fellowships, and in locum tenens staffing also may be helpful in addressing the provider shortage and expanding access to care. Changes to scope of practice laws could increase the workforce by allowing mid-level providers and pharmacists to provide more services.

Telemedicine offers great promise for expanding access to care in rural areas, but several challenges remain. For one, as mentioned above, broadband connectivity must be addressed. Significant "broadband deserts," especially in rural America, remain. ${ }^{64}$ Supervision, interstate licensure, data interoperability, and reimbursement challenges also require attention. At present, Medicare reimbursement for telemedicine is limited to designated rural areas, with wide state variation regarding Medicaid and private insurance reimbursement, as well as other state laws governing telehealth. ${ }^{65}$

As discussed above, the financial sustainability of rural hospitals is a pressing concern. Medicaid expansion, if not a magic bullet, would certainly go a long way to shoring up struggling facilities. A recent study concluded that Medicaid expansion was associated with improved financial performance and substan- 
tially reduced the likelihood of closure for rural hospitals. ${ }^{66}$ The study concluded that replacing uncompensated care with Medicaid coverage improved hospitals' financial margins enough to avert closure. ${ }^{67}$ Although Medicaid reimbursement rates are considerably lower than other third-party payers, something is better than nothing.

The overall trend of increased health care consolidation also is relevant for rural hospitals seeking a lifeline. That said, health systems that acquire previously independent rural hospitals may not have financial motivation to maintain those facilities as going concerns across their portfolios. In other cases, vulnerable hospitals simply may not be attractive for acquisition in the first place. In Georgia, one of our particular challenges is the prevalence of quasi-governmental hospital authorities. ${ }^{68}$ As those facilities face financial vulnerability, they may seek access to other revenue streams by reorganizing under different corporate forms through mergers, acquisitions, or bankruptcy. But even the cost of legal fees for those transactions may be prohibitive for many rural facilities. High transaction costs can impede other strategies for staying afloat. For example, certain U.S. Department of Agriculture loans are available to rural health care providers, but they would need grant-writing and administrative resources to access that funding. ${ }^{69}$

Where general acute care hospitals are not sustainable, owners, operators, and communities may look to alternatives, including freestanding emergency departments $^{70}$ and "micro" hospitals..$^{71}$ Those forms would have to run the gauntlet of state facility licensing and certificate of need laws, where applicable. Moreover, even where permitted by state law, questions remain regarding reimbursement for stand-alone emergency services and other novel facility forms.

Other rural health strategies and demonstration projects focus on integration and coordination of care. Some utilize existing models such as Patient-Centered Medical Homes, which can be organized fairly readily without major capital costs around primary care providers, and Accountable Care Organizations, which offer potential new revenue streams but require more upfront resource and capital investment to achieve. ${ }^{72}$ New models are also promising. For example, the Frontier Community Health Integration Project, involving ten critical access hospitals in Montana, Nevada, and North Dakota, ${ }^{73}$ is testing new models for health care delivery in frontier areas including providing certain essential services in patients' home communities, rather than transferring them to distant facilities. Health Extension Rural Offices (HERO) ${ }^{74}$ is a New Mexico Model that operates similarly to agricultural extension services but for health. HERO agents live in rural communities, serving as resources to local health providers on the latest best practices, encouraging young people to finish school and pursue health careers, recruiting and retaining a health care work force, and strengthening local capacity to address local health problems.

A variety of public health strategies also may be helpful, including health promotion and education of both health workers and the public.

\section{Conclusion}

Poverty in rural America exhibits unique causes and challenges. Rural health care access is particularly fraught. Accordingly, rural health care interventions, with respect to both health care delivery and public health promotion, need to be uniquely tailored to this subpopulation of the American poor.

Note

The author has no conflicts to disclose.

\section{References}

1. See, e.g., "About RUPRI," RUPRI, available at <http://www. rupri.org/about-rupri/> (last visited July 11, 2018).

2. P. Domm, "Goldman Says This May Become the Longest Economic Expansion in History," CNBC, May 8, 2017, available at <https://www.cnbc.com/2017/05/08/goldman-says-u-seconomy-may-be-slowly-growing-into-the-longest-expansionin-history.html> (last visited July 11, 2018).

3. K. D. Kochanek, E. Arias, and R. N. Anderson, "Leading Causes of Death Contributing to Decrease in Life Expectancy Gap Between Black and White Populations: United States, 1999-2013," NCHS Data Brief, no. 218 (2015): 1-7, at 1, available at <https://www.cdc.gov/nchs/data/databriefs/db218. pdf $>$ (last visited July 11, 2018).

4. S. Brasch, "Is the Economic Recovery Leaving Rural America Behind?," Modern Farmer, December 5, 2013, available at $<$ https://modernfarmer.com/2013/12/economic-recoveryleaving-rural-america-behind/> (last visited July 11, 2018)

5. G. K. Singh and M. Siahpush, "Widening Rural-Urban Disparities in Life Expectancy, U.S., 1969-2009,” American Journal of Preventative Medicine 29, no. 2 (2014): e19-e29, available at <http://www.ajpmonline.org/article/S07493797(13)00590-4/pdf> (last visited July 11, 2018).

6. Patient Protection and Affordable Care Act, Pub. L. No. 111148, 124 Stat. 119 (March 23, 2010); Health Care and Education Reconciliation Act of 2010, Pub. L. No. 111-152, 124 Stat. 1029 (March 30, 2010).

7. See, e.g., Rural Policy Research Institute, "About RUPRI," RUPRI, available at <http://www.rupri.org/about-rupri/> (last visited July 11, 2018); see also D.Williams Jr. and M. Holmes, "Rural Health Care Costs: Are They Higher and Why Might They Differ from Urban Health Care Costs?," North Carolina Medical Journal 79, no. 1 (2018): 51-55, available at <http://www.ncmedicaljournal.com/content/79/1/51.full. pdf + html > (last visited July 11, 2018); " 6 Charts that Illustrate the Divide Between Rural and Urban America," $P B S$ Neres Hour, March 17, 2016, available at <https://www.pbs. org/newshour/nation/six-charts-illustrate-divide-rural-urbanamerica> (last visited July 11, 2018).

8. $\quad$ See $i d$.

9. U.S. Department of Agriculture, Economic Research Service, "Rural Poverty \& Well-being," available at <https://www.ers. 
usda.gov/topics/rural-economy-population/rural-poverty-wellbeing/> (last visited July 11, 2018).

10. See $i d$.

11. See $i d$.

12. See generally A. R. Tickamyer, J. Sherman, and J. Warlick, eds., Rural Poverty in the United States (New York: Colombia University Press, 2017)

13. P. Dudenhefer, Poverty in the Rural United States, Persistent Poverty in Rural America (Boulder: Westview Press 1993): 37-46, available at <https://www.irp.wisc.edu/publications/ focus/pdfs/foc151c.pdf> (last visited February 12, 2018); B. Thiede, L. Greiman, S. Weiler, S. Beda, and T. Conroy, "6 Charts That Illustrate the Divide Between Rural and Urban America," PBS, March 17, 2017, available at <https://www. pbs.org/newshour/nation/six-charts-illustrate-divide-ruralurban-america> (last visited July 11, 2018).

14. L. K. Gurley, "Why the Left Isn't Talking About Rural American Poverty," In These Times, October 22, 2015, available at $<$ http://inthesetimes.com/rural-america/entry/18526/whythe-left-isnt-talking-about-rural-american-poverty> (last visited July 11, 2018).

15. See $i d$.

16. T. Misra, "A Complex Portrait of Rural America," CityLab, December 8, 2016, available at <https://www.citylab. com/equity/2016/12/a-complex-portrait-of-rural-america $/ 509828 />$ (last visited July 11, 2018).

17. Gurley, supra note 14.

18. A. MacGillis, "The Original Underclass," The Atlantic, September 2016, available at <https://www.theatlantic.com/ magazine/archive/2016/09/the-original-underclass/492731/> (last visited July 11, 2018)("The barely veiled implication...is that the people undergoing these travails deserve relatively little sympathy - that they maybe, kinda had this reckoning coming. Either they are layabouts drenched in self-pity or they are sad cases consumed with racial status anxiety and animus toward the nonwhites passing them on the ladder.").

19. See Gurley, supra note 14.

20. See K. B. Kozhimannil and C. Henning-Smith, "Racism and Health in Rural America," Journal for the Health Care of the Poor and Underserved 29, no. 1 (November 22, 2017): 35-43, available at <https://preprint.press.jhu.edu/sites/default/ files/KozhimannilFinalCE\%20preprint.pdf> (last visited July 11, 2018).

21. K. Frederique and M. Moore, "Opioids Became a Crisis Because They Kill So Many White Americans," The Hill, November 13, 2017, available at <http://thehill.com/opinion/ healthcare/360162-opioids-became-a-crisis-because-theykill-so-many-white-americans> (last visited July 11, 2018).

22. Mortality and Life Expectancy in Rural America: Connecting the Health and Human Service Safety Nets to Improve Health Outcomes Over the Life Course, National Advisory Committee on Rural Health and Human Services Policy Brief (October 2015): 1-10, at 1, available at <https://www.hrsa.gov/advisorycommittees/rural/publications/mortality.pdf > (last visited July 11, 2018).

23. See $i d$. at 2 .

24. See $i d$. at 7-8,9.

25. "Rural Americans at Higher Risk of Death From Five Leading Causes," CDC, January 12, 2017, available at <https:/www. cdc.gov/media/releases/2017/p0112-rural-death-risk.html> (last visited January 25, 2018).

26. See $i d$.

27. See $i d$. at $1545-1546$.

28. See $i d$. at $1545-1546$.

29. See $i d$. at 1545 .

30. A. Case and A. Deaton, "Rising Morbidity and Mortality in Midlife Among White Non-Hispanic Americans in the 21st Century," PNAS 112, no. 49 (2015): 15078-15083.

31. See $i d$. at 15081 .

32. See, e.g., D. Friedsam, "Does the Rural-Urban Frame Help Explain Health Status?” Health Affairs Blog, April 30,
2018, available at <https://www.healthaffairs.org/do/10.1377/ hblog20180426.201480/full/> (last visited July 11, 2018).

33. See, e.g., J. Auerbach and A. Gelman, "Age-Aggregation Bias in Mortality Trends," PNAS 113, no. 7 (2016): E816-E817, available at <https://doi.org/10.1073/pnas.1523465113> (last visited July 11, 2018); J. Auerbach and A. Gelman, "Stop Saying White Mortality Is Rising," Slate, March 28, 2017, available at <http://www.slate.com/articles/health_and_science/ science/2017/03/is_white_mortality_rising_not_really.html> (last visited June 22, 2018); J. Guo, "How dare you work on whites': Professors under fire for research on white mortality," The Washington Post, April 6, 2017, available at <https://www. washingtonpost.com/news/wonk/wp/2017/04/06/how-dareyou-work-on-whites-professors-under-fire-for-research-onwhite- mortality/?noredirect=on\&utm term $=.7 \mathrm{~d} 7323 \mathrm{e} 3 \mathrm{a} 4 \mathrm{ba}>$ (last visited July 11, 2018); A. Semuels, "Is Economic Despair What's Killing Middle-Aged White Americans?" The Atlantic, March 23, 2017, available at <https://www.theatlantic.com/ business/archive/2017/03/economic-despair/520473/> (last visited June 22, 2018)

34. See C. V. James et al., "Racial/Ethnic Health Disparities Among Rural Adults - United States, 2012-2015," Centers for Disease Control \& Prevention, Morbidity and Mortality Weekly Report 66, no. 3 (2017), available at <https://www. cdc.gov/mmwr/volumes/66/ss/ss6623a1.htm> (last visited July 11, 2018) (noting that although rural populations are less diverse, rural racial/ethnic minority populations suffer substantial health, access to care, and lifestyle challenges that should not be overlooked).

35. J. Johnson and J. Wagner, "Trump Declares the Opioid Crisis a Public Health Emergency," The Washington Post, October 26, 2017, available at <https://www.washingtonpost.com/ news/post-politics/wp/2017/10/26/trump-plans-to-declarethe-opioid-crisis-a-public-health-emergency/?utm_term $=$. a48bcea0297e >(last July 11, 2018).

36. L. Runyon, "Why is the Opioid Epidemic Hitting Rural America Especially Hard?” NPR, January, 4, 2017, available at <http://nprillinois.org/post/why-opioid-epidemic-hittingrural-america-especially-hard\#stream/0> (last visited January $25,2018)$

37. Substance Abuse Research Alliance, "Prescription Opioids and Heroin Epidemic in Georgia-A White Paper," (2017):160, available at <http://www.senate.ga.gov/sro/Documents/ StudyCommRpts/OpioidsAppendix.pdf> (last visited July 11, 2018).

38. C. A. Cunningham, "The Opiate Crisis in Rural America," National Association of State EMS Officials, available at $<$ https://www.nasemso.org/Advocacy/PositionsResolutions/ documents/The-Opiate-Crisis-in-Rural-America.pdf $>$ (last visited January 25, 2018).

39. B. DiJulio, A. Kirzinger, B. Wu, and M. Brodie, "Data Note: Americans' Challenges with Health Care Costs," The Henry J. Kaiser Family Foundation, March 2, 2017, available at $<$ https://www.kff.org/health-costs/poll- finding/data-noteamericans-challenges-with-health-care-costs/> (last visited July 11, 2018).

40. A. R. Barker et al., Health Insurance Marketplaces: Premium Trends in Rural Areas, RUPRI Center for Rural Health Policy Analysis Rural Policy Brief, May 2016, available at <https:// www.public-health.uiowa.edu/rupri/publications/policybriefs $/ 2016 /$ HIMs\%20rural\%20premium\%20trends.pdf > (last visited July 11, 2018); Williams and Holmes, supra note 7 , at 53-54.

41. O. Khazan, "Why are ther so Few Doctors in Rural America," The Atlantic, August 28, 2018, 2014, available at <https:// www.theatlantic.com/health/archive/2014/08/why-wont-doctors-move-to-rural-america/379291/> (last visited September 14, 2018).

42. "Meeting the Primary Care Needs of Rural America: Examining the Role of Non-Physician Providers," National Conference of State Legislatures, available at <http://www.ncsl.org/ 
research/health/meeting-the-primary-care-needs-of-ruralamerica.aspx $>$ (last visited September 14, 2018).

43. "About Rural Health Care," National Rural Health Association, available at <https://www.ruralhealthweb.org/about-nrha/ about-rural-health-care > (last visited January 25, 2018); see Substance Abuse Research Alliance, supra note 37, at 5 (discussing shortage of substance abuse and medication-assisted treatment in rural areas).

44. "83 Rural Hospital Closures: January 2010-Present," UNC: The Cecil G. Sheps Center for Health Services Research, available at <http://www.shepscenter.unc.edu/programs-projects/ rural-health/rural-hospital-closures/> (last visited January 25, 2018).

45. See $i d$.

46. "Rural Hospital Closures Since 2010," Stroudwater, July 7, 2017, available at <http://www.stroudwater. com/?resources=analyses-rural-hospital-closures-since-2010 $>$ (last visited July 11, 2018).

47. "CMS Proposes \$43B in Cuts to Disproportionate Share Hospital Payments," Advisory Board, July 31, 2017, available at <https://www.advisory.com/daily-briefing/2017/07/31/dshcuts> (last visited July 11, 2018).

48. J. Wishner, P. Solleveld, R. Rudowitz, J. Paradise, and L. Antonisse, "A Look at Rural Hospital Closures and Implications for Access to Care: Three Case Studies," The Henry J. Kaiser Family Foundation, July 7, 2016, available at <https:// www.kff.org/report-section/a-look-at-rural-hospital-closuresand- implications-for-access-to-care-three-case-studies-issuebrief/> (last visited July 11, 2018).

49. See S. Percy, "Georgia's Hospitals: Rural Hospitals In Crisis," Georgia Trend, December 2016, available at <http://www. georgiatrend.com/December-2016/GEORGIAs-HOSPITALSRural-Hospitals-In-Crisis/> (last visited July 11 2018).

50. U.S. Internal Revenue Service, "New Requirements for 501(c) (3) Hospitals Under the Affordable Care Act," available at <https://www.irs.gov/charities-non-profits/charitable-organizations/new-requirements-for-501c3-hospitals-under-theaffordable-care-act> (last visited July 11, 2018); R. Daly, "IRS Makes First Revocation of Hospital Not-for-Profit Exemption Under 501 ${ }^{\circledR}$, , HFMA, August 15, 2017, available at <https:// www.hfma.org/Content.aspx?id=55271> (last visited July 11, 2018).

51. See Percy, supra note 49.

52. National Federation of Independent Business v. Sebelius, 567 U.S. 519, 587-88 (2012).

53. S. Luthra, "Lack of Medicaid Expansion Hurts Rural Hospitals More Than Urban Facilities," Kaiser Health Neres, September 7, 2016, available at <https://khn.org/news/lack-of-medicaidexpansion-hurts-rural-hospitals-more-than-urban-facilities/> (last visited July 11, 2018).

54. R. C. Lindrooth, M. C. Perraillon, R. Y. Hardy, and G. J. Tung, "Understanding The Relationship Between Medical Expansions and Hospital Closures," Health Affairs 37, no. 1 (2018): 111-120, at 117-119.

55. A. R. Barker, L. M. Kemper, T. D. McBride, and K. J. Mueller, Rural Policy Brief: Health Insurance Marketplaces: Premium Trends in Rural Areas, RUPRI Center for Rural Health Policy Analysis, available at $<$ https://cph.uiowa.edu/rupri/publications/policybriefs/2016/HIMs\%20rural\%20premium $\% 20$ trends.pdf> (last visited July 11, 2018).

56. See $i d$.

57. See $i d$.; see also A. Semanskee et al., "Insurer Participation on ACA Marketplaces, 2014-2018," Henry J. Kaiser Family Foundation, Health Reform, November 10, 2017, available at <https://www.kff.org/health-reform/issue-brief/insurer-participation-on-aca-marketplaces/> (last visited July 11, 2018).

58. R. Gelburd, "Federal Open Enrollment Now Even Shorter Than It Was Before," The Hill, October 6, 2017, available at <http://thehill.com/opinion/healthcare/354229-federal- open-enrollment-period-is-now-shorter-than-it-was-before> (last visited July 11, 2018).

59. D. Mangan, "Trump Administration Health Reps Told Not to Participate in Obamacare Outreach Nationwide, as Advocates Claim 'sabotage," CNBC, September 27, 2017, available at <https://www.cnbc.com/2017/09/27/federal-health-repstold-not-to-participate-in-obamacare-outreach.html> (last visited July 11, 2018).

60. J. Eilperin, A. Goldstein, and C. Y. Johnson, "White House's Decision to Stop ACA Cost-Sharing Subsidies Triggers Strong Opposition," The Washington Post, October 13, 2017, available at <https://www.washingtonpost.com/politics/white-housetells-court-it-is- immediately-stopping-aca-cost-sharing-sub sidies/2017/10/13/4c404234-b01d-11e7-be94-fabbofle9ffb story.html?utm term=.bd396e2c5818 > (last visited July 11, 2018).

61. T. Jost, "The Tax Bill and the Individual Mandate: What Happened, and What Does It Mean?" Health Affairs, December 20 2017, available at <https://www.healthaffairs.org/do/10.1377/ hblog20171220.323429/full/> (last visited February 12, 2018).

62. See D. Gorenstein and J. Kasperkevic, "Health Care Premiums for 2018 Set to Go up by as Much as 50 Percent," Marketplace, October 5, 2017, available at <https://www.marketplace. org/2017/10/05/health-care/uncertainty-healthcare-premiums-increase-2018-50-percent> (last visited July 11, 2018).

63. See 42 C.F.R. $\$ 1001.952(n)(8)$.

64. See, e.g., A. G. Sheinin, "Broadband Deserts' Hinder Growth in Rural Georgia," The Atlanta Journal-Constitution, June 11, 2017, available at <http://politics.myajc.com/news/state--regional-govt--politics/broadband-deserts-hinder-growth-ruralgeorgia/Fx3iwMdptBtTfMpdz0CgtJ/> (last visited July 11, 2018).

65. J.T. Ripton and C. S. Winkler, "How Telemedicine is Transforming Treatment in Rural Communities," Becker's Healthcare, April 8, 2016, available at <https://www.beckershospitalreview.com/healthcare-information-technology/how-telemedicine-is-transforming-treatment-in-rural-communities.html> (last visited July 11, 2018).

66. See Lindrooth, supra note 54, at 111.

67. See $i d$.

68. See O.C.G.A. \$ 31-7-72

69. Weldon Freeman, Press Release No. 0151.17: "USDA Invests More Than \$1 Billion to Improve Health Care in Rural Areas," USDA, November 17, 2017, available at <https://www.usda. gov/media/press-releases/2017/11/17/usda-invests-more-1-billion-improve-health-care-rural-areas $>$ (last visited July 11, 2018).

70. B. Herman, "When the Tiny Hospital Can't Survive: Freestanding EDs With Primary Care Seen as New Rural Model,' Modern Healthcare, September 27, 2014, available at <http:// www.modernhealthcare.com/article/20140927/MAGAZINE/309279952> (last visited July 11, 2018).

71. J. Nolin, "Rural Hospital Measure Clears Path for 'micro' Hospitals," Tifton Gazette, February 7, 2018, available at <http:// www.tiftongazette.com/news/rural-hospital-measure-clearspath-for-micro-hospitals/article_97115402-0c33-11e8-861eob6ca029e873.html> (last visited July 11, 2018).

72. See Rural Health Information Hub, "Rural Care Coordination Toolkit," available at <https://www.ruralhealthinfo.org/toolkits/care-coordination> (last visited July 11, 2018).

73. "Frontier Community Health Integration Project (FCHIP)," Rural Health Information Hub, available at <https://www. ruralhealthinfo.org/new-approaches/frontier-communityhealth-integration-program> (last visited July 11, 2018).

74. "Health Extension Rural Offices (HEROs)," Rural Health Information Hub, October 11, 2017, available at <https:// www.ruralhealthinfo.org/community-health/project-examples/981> (last visited July 11, 2018). 